\title{
Economic impact of Melanaphis sacchari (Zehntner) on Sorghum bicolor (L.) Moench, and its management in the Southwestern of Puebla, Mexico
}

\section{Serratos-Tejeda, Carlos ${ }^{1}$, Morales-Jiménez, Juan ${ }^{1 *}$, Huerta-de la Peña, Arturo ${ }^{1}$, Hernández-Salgado, José Hilario ${ }^{1}$, Villanueva-Jiménez, Juan A. ${ }^{2}$, Aragón-García, Agustín ${ }^{3}$}

\begin{abstract}
${ }^{1}$ Colegio de Postgraduados Campus Puebla, Puebla, México, C.P. $72760 .{ }^{2}$ Colegio de Postgraduados Campus Córdoba, Córdoba, Veracruz, México, C.P. $94946 .{ }^{3}$ Centro de Agroecología, Instituto de Ciencias, Benemérita Universidad Autónoma de Puebla, Puebla, México, C.P. 72960.
\end{abstract}

*Corresponding author: morales@colpos.mx

\begin{abstract}
Objective: To evaluate the economic impact of sorghum aphid (Melanaphis sacchari) and the sorghum crop profitability in Western Puebla, Mexico, considering the management practices application-index (IAPM), related to the control practices suggested by the State Plant Health Committee (CESAVEG).
\end{abstract}

Design/Methodology/Approach: Data on socioeconomic aspects of the producer and the production units were collected. The questionnaire was applied to producers affiliated to PROAGRO. Results are shown using descriptive statistics.

Results: The aphid infestation in sorghum had its most relevant effect on yield during 2014-2016. Income obtained from sorghum sales is decreasing due to a downward trend in the purchase price per ton. After the arrival of M. sacchari, the primary control strategy was to increase the number of insecticide applications, increasing production costs.

Limitations of the study/implications: Since producers' incomes do not depend solely on sorghum production, the effect of the pest on their economy was relatively minor.

Findings/Conclusions: The management practices application index indicates a moderate use of the recommended practices to manage this pest. The B/C ratio suggests that even after the establishment of $M$. sacchari, sorghum is still a profitable activity.

Keywords: Pest management, injuries, profitability.

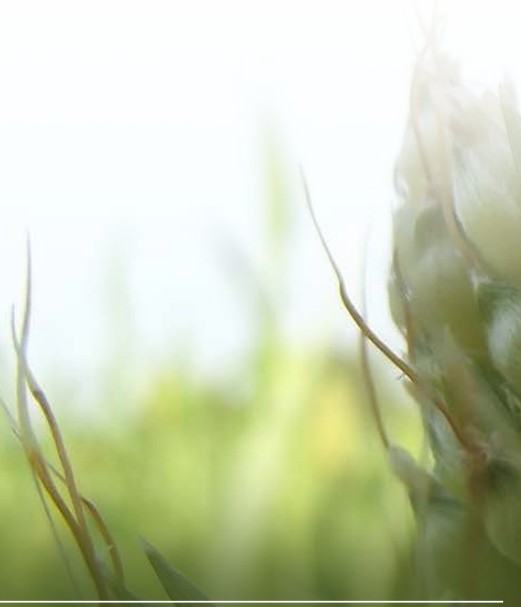

Agroproductividad: Vol. 14, Núm. 4, abril. 2021. pp: 3-9. Recibido: junio, 2020. Aceptado: febrero, 2021. 
INTRODUCTION

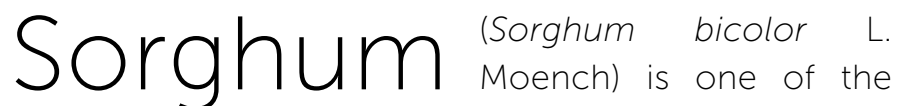
main crops in Mexico; it is a raw material for balanced feed for livestock industry (SAGARPA, 2012). 75.7\% of the production of Puebla state is concentrated in 46 municipalities of the Southwestern region (Vargas, 2009; SIAP, 2017). Sorghum yellow aphid [Melanaphis sacchari (Zehntner)] represents a phytosanitary problem in this region. In 2013, this pest was detected for the first time in Mexico in the state of Tamaulipas, where infestation levels caused severe damages and losses ranging from 30 to $100 \%$. It is currently present in all states where sorghum is sown (INIFAP-CIRNE, 2015). Damages caused by $M$. sacchari include desiccation, necrosis, delayed seedling growth and panicle appearance. If damage is severe, the plant dies. These damages have an impact on crop yield (Singh et al., 2004; Bowling et al., 2016). In addition, expenses on control tactics are associated with the application of insecticides (Oliveira et al., 2013).

Although there are strategies to control sorghum aphid, their implementation depend on the cultural, physical, biological, technical, social, and economic context in which the crop is grown (Rivas and Sermeño, 2004; Savary et al., 2006a, b)

Production costs have increased due to a greater number of insecticide applications used to control M. sacchari. In addition, there has been a continuous reduction in the price paid per ton of sorghum. Nevertheless, this crop is still sown in the region. It is necessary to know the strategies and modifications implemented in the production system to reduce damages caused by sorghum aphid, as well as to analyze the costs and benefits obtained from planting this grain in order to determine the reason for its continued use. For these purposes, the objective of this study was to assess the economic impact of $M$. sacchari and sorghum crop profitability in the Southwestern region of Puebla state, Mexico, considering the Management Practices Application-Index (IAPM) recommended by CESAVEG for sorghum production systems.

\section{MATERIALS AND METHODS \\ Geographical Framework of the Study}

The research was carried out in the Southwestern region of Puebla state, between parallels $18^{\circ} 00^{\prime}$ and $19^{\circ} 51^{\prime} \mathrm{N}$ and meridians $97^{\circ} 49^{\prime}$ and $98^{\circ} 47^{\prime} \mathrm{W}$.

\section{Sample Size}

A questionnaire containing questions regarding socioeconomic aspects, production process and commercialization of sorghum was prepared. A sample (n) of beneficiary producers of the "PROAGRO PRODUCTIVO" federal program responded the questionnair. The sample was estimated with a maximum variance based on the following formula:

$$
n=\frac{N Z_{\alpha / 2}^{2}(.25)}{N d^{2}+Z_{\alpha / 2}^{2}(.25)}
$$

Where: $N=1730$ producers who are beneficiaries of "PROAGRO"; $z_{\alpha / 2}^{2}=1.96$ (value of normal distribution table); and $\alpha=0.05$ (95\% reliability).

The sample consisted of 91 producers producers were distributed as follows: Tepexco: 20, Izúcar de Matamoros: 19, Atzizihuacán: 14, Acteopan: 10, Tilapa: 8, Huehuetlán el Chico: 6, Xochiltepec: 7, Atzala: 5, Jolalpan: 1, and Huehuetlán el Grande: 1.

\section{Economic Impact of M. sacchari on Sorghum Production}

The following topics were covered in the questionnaire: producers' perception of the impact of sorghum aphid on sorghum yields, their knowledge of the damage it causes, the first cycle with infestation, the varieties planted, the insecticides applied, and the technical assistance received.

\section{Changes Implemented into Agricultural System to Manage Sorghum Aphid Populations}

Producers were sought to represent the changes in sorghum production system, and other activities developed to reduce losses due to sorghum aphid.

\section{Management Practices Application-Index (IAPM, for its Spanish Acronym)}

The IAPM, derived from the one proposed by DamiánHuato et al. (2019), was calculated, and applied to compare the recommendations set out in $M$. sacchari Management Guide by CESAVEG (2017), with practices implemented by producers. A value of 100 points was assigned to the total number of recommendations and these were weighed according to their impact on $M$. sacchari management: 10 points if they know how to locate and identify it, 5 points if they know the damage, 10 points if they identify beneficial fauna, 15 
points if they eliminate infestation sources, 5 points if they use a certified seed, 10 points if they use seeds treated with insecticide, 15 points if they check the crop frequently, 10 points if they protect and allow beneficial fauna to act, and 20 points if they apply recommended products at the proposed dosage. Each weighted value was divided by two, where the first quotient represented the use recommended practice, and the second one to the practices actually carried out. The IAPM was calculated with the following equation:

$$
I A P M=\sum_{i=1}^{k}[(p i)(P A P i / P G M i)]
$$

Where: Management Practices Application-Index (IAPM); $K=$ Number of Best Practices contained in Sorghum Aphid Management Guide prepared by CESAVEG (2017), where $\max K=9$; Pi: Weighing given to the $i$-th element the recommendation; $P A P i=$ Practices applied for the $i$-th recommendation element; $i=1,2 \ldots k$; where $\sum_{i=1}^{k} K i=1(p i)=100, i=1,2 \ldots k$; PGMi: Practices of the management guide for the $i$-th component of the recommendation; $i=1,2 \ldots K$, where $(P A P i / P G M i)=$ Ratio of practices applied against those recommended.

Once the IAPM has been calculated, the typology of producers was prepared by grouping them according to the value obtained: low $(<33.33)$ medium $(33.34$ to 66.66) and high (>66.66).

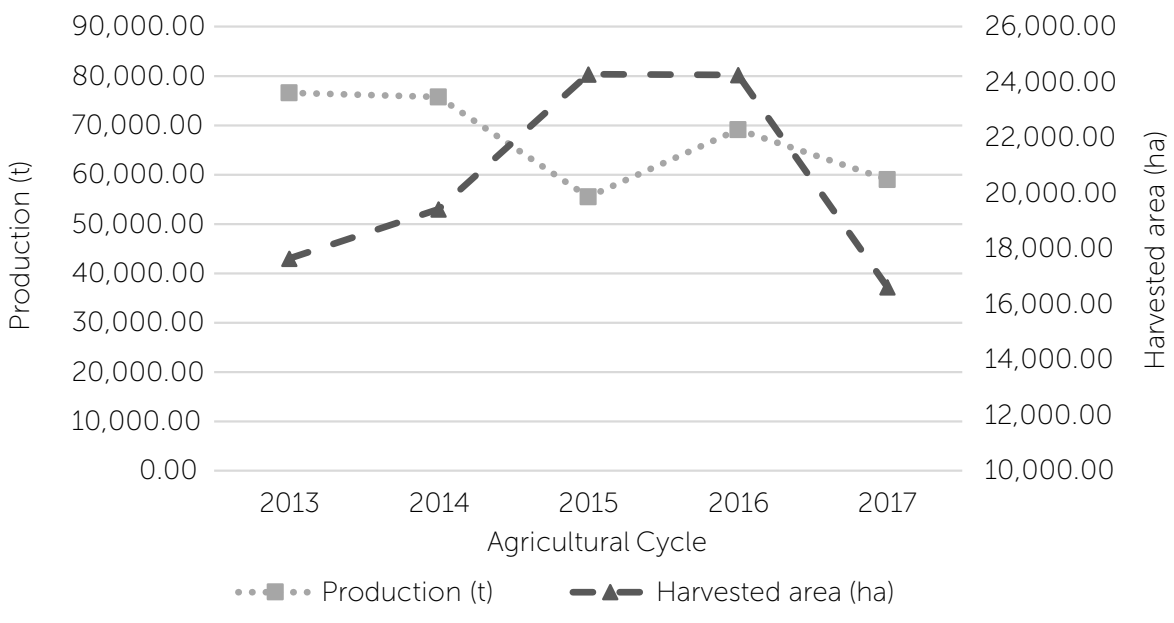

Figure 1. Sorghum production in the Southwestern region of Puebla state. (Prepared from SIAP data, 2019).

\section{Crop Profitability both Under Traditional Farming and No-Till Farming Systems}

Crop profitability was examined for 2017 cycle, under both systems implemented within the area: traditional farming and no-till farming. In both cases, production costs per hectare were determined based on the type of technology used by an average producer. Land preparation, inputs, contracted services, and indirect production costs were considered. Benefit-cost ratio was used as a profitability indicator, calculated according to Sobrado (2005):

$$
C / B R=(S /) /(C H)
$$

Where: $C / B R=$ Cost-benefit ratio; $S /=$ Sales Income; $\mathrm{CH}=$ Cost per hectare.

If the C/BR index is higher than 1.0, the portion in which it exceeds the unit will indicate the level of profitability of the crop.

\section{RESULTS AND DISCUSSION \\ Impact of $M$. sacchari on Sorghum Production in the Southwestern Region of Puebla state}

Majority (98.9\%) of producers responded that their crops have been adversely affected by sorghum aphid. According to these producers, this pest causes the following issues: it dries up the plant (83.5\%), lowering grain weight $(13.2 \%)$ and growth of panicle $(3.3 \%)$. Not all producers coincided with the initial infestation of the aphid: $56 \%$ of producers remember that it took place in 2015 , but $44 \%$ said it was in 2014 . The arrival of sorghum aphid to the region adversely affected crop yield: although 1775 additional hectares were sown in 2014 compared to 2013, the yield was 1.1\% lower. This worsened in 2015, when production was 28\% lower, although the area sown was larger. Besides the difference of areas sown between 2013 and 2017 is 1040 ha, the yield for the first cycle was $28.1 \%$ higher (Figure 1).

In the region, the average sorghum yield was $3.9 \mathrm{t} \mathrm{ha}^{-1}$ in 2014, and in 2015, $2.28 \mathrm{t} \mathrm{ha}^{-1}$. These cycles were considered of greater infestation, with yields lower than those in 2013 (4.34 $\mathrm{t} \mathrm{ha}^{-1}$ ) (SIAP, 2017). In 2014 
and 2015 nine varieties were sown (ACA506, ACA6001, ACA642, AMBAR, ANZU310, ARGOS, DEKALB, El CAMINO and GALIO). DEKALB, the variety sown to a greater extent $(57.1 \%$ of producers), is classified as a hybrid tolerant to M. sacchari (SAGARPA-INIFAP, 2017). The use of plant resistance is part of a strategy to reduce damages caused by sorghum aphid to grain sorghum crops (Haar et al., 2019).

In 2014 and 2015 cycles, $87.9 \%$ of the producers applied insecticides. Imidacloprid (imidacloprid) was the most used product (84.1\%), followed by Curacron (profenofos, 4.9\%), Folidol (parathion, 3.7\%), Disparo (chlorpyrifos-ethyl, 1.2\%), and Malathion (malathion, 1.2\%); while $3.7 \%$ of producers applied a mix of two or more of these insecticides and 1.2\% applied alternative methods such as soap or ammonia. A low number (12.1\%) of producers did not implement any control strategy, since they did not know the pest.

Yield distribution for 2014-2017 cycles is shown in Table 1. In 2014 and 2015 cycles, the yield observed is lower than $3 \mathrm{t} \mathrm{ha}^{-1}$ for a higher percentage of producers, as opposed to what was recorded in 2016 and 2017, when yields were higher than $3 \mathrm{t} \mathrm{ha}^{-1}$ for most of them.

Purchase price per ton has been falling in the region. In 2015, average purchase price was MX\$3337.91, which was the highest price detected (Figure 2).

Due to a reduction in purchase price, combined with less production, revenues were lower than 2013, the cycle previous to the arrival of $M$. sacchari to the Southwestern region of Puebla state. The lowest income was obtained during 2014 and 2015 cycles (Table 2)

\section{Changes Implemented into Agricultural System to Manage Sorghum Aphid Populations}

The strategies implemented to control M. sacchari are an increased frequency of insecticide application (44\%); crop inspection (21\%); and change of insecticide (14\%). Due to losses, $9 \%$ of producers did not seed in the next cycle, $10 \%$ sought advice, and and only $2 \%$ continued with the insecticide applied in the previous cycle. According to Aguilar (2005), intrusive species reduce crop yield, increase production costs, and the frequency of agrochemical use, which also was observed in this research.

In $91 \%$ of the cases, the effect of sorghum aphid on the producer's economy was relatively minor, since their income does not depend solely on sorghum profits. Their primary activities are: sugarcane sowing (35\%), amaranth sowing (15\%), peanut sowing (12\%), corn sowing $(11 \%)$, onion sowing $(2 \%)$, stockbreeding $(3 \%)$, aquaculture (1\%); in addition to secondary activities, such as pottery (10\%), as well as tertiary activities, such as their small businesses (2\%) (grocery store and "huarache" shoe sale). The above agrees with that stated by FAO (2012): family farming represents the main source of income, but it can be supplemented with other non- 
agricultural activities. In this context, FAO (2001) stated that the effect of pests on producers' economy is mitigated by extra sources of income. However, this effect also depends on the producer's own adaptation, the reconsideration of the productive system, the availability of economic reserves, or even selling or pawning goods.

\section{Management Practices Application Index (IAPM)}

Two thirds (65.78\%) of producers who use traditional farming showed a medium level in IAPM. In addition, most of the producers with no-till farming (85.7\%) showed a medium level in IAMP (Figure 3). According to Damián-Huato et al. (2011), crop yield is the result of multiple factors, including the technological component, which should be used appropriately to be relevant. In both farming types, those with a higher IAPM also obtained a higher yield.

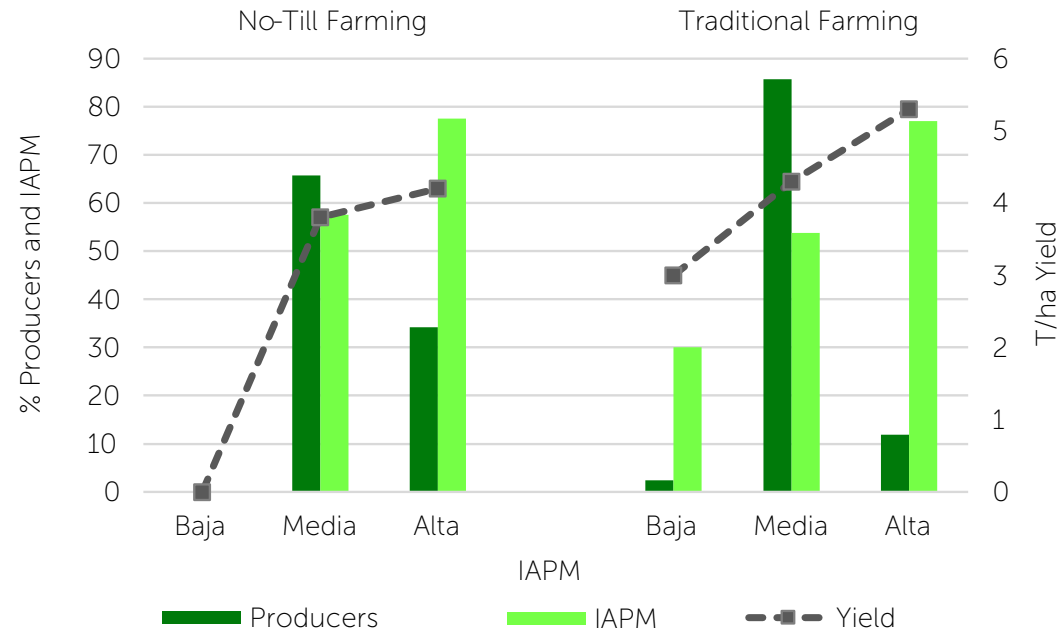

Figure 3. Percentage of producers and yield with respect to IAPM obtained in the Southwestern region of Puebla state.

\section{Profitability of Grain Sorghum Cultivation}

Production cost using traditional farming for 2017 was $\$ 11,520.44 \mathrm{ha}^{-1}$. Land preparation represented $24.21 \%$ of production costs, supplies $41.48 \%$, hired services

\begin{tabular}{|c|c|c|c|c|c|c|}
\hline \multirow{2}{*}{ Activity } & \multicolumn{3}{|c|}{ Traditional Farming } & \multicolumn{3}{|c|}{ No-Till Farming (Zero) } \\
\hline & Qty. & Cost ha ${ }^{-1}$ & Total (\$) & Qty. & Cost ha ${ }^{-1}$ & Total (\$) \\
\hline Tasks & & & 2789.42 & & & 911.76 \\
\hline Fallow & 1 & 968.57 & 968.57 & & & \\
\hline Tracking & 1 & 914.28 & 914.28 & & & \\
\hline Planting & 1 & 906.57 & 906.57 & 1 & 911.76 & 911.76 \\
\hline Supplies & & & 4778.83 & & & 5654.02 \\
\hline Gesaprim 90 & & & & $2.5 \mathrm{~L}$ & 182.15 & 455.37 \\
\hline Jornal & & & & 2 & 163.84 & 327.68 \\
\hline DEKALB & $19 \mathrm{~kg}$ & 30.96 & 588.24 & $18.9 \mathrm{~kg}$ & 30.17 & 570.21 \\
\hline $1^{\text {st }}$ Fertilization & \multicolumn{2}{|c|}{ Included in planting } & 1511.03 & \multicolumn{2}{|c|}{ Included in planting } & 1214.81 \\
\hline $2^{\text {nd }}$ Fertilization & & & 749.21 & & & 1095.36 \\
\hline Jornal & 2 & 162.81 & 325.62 & 2 & 267.77 & 535.54 \\
\hline Imidacloprid & $0.379 L$ & 686.22 & 260.70 & 0.585 & 691.67 & 404.62 \\
\hline Jornal & 2 & 159.03 & 318.06 & 2 & 181.71 & 363.42 \\
\hline Gesaprim 90 & $1.81 \mathrm{~L}$ & 188.02 & 340.31 & 2.52 & 127.41 & 321.07 \\
\hline Jornal & 2 & 162.83 & 325.66 & 2 & 182.97 & 365.94 \\
\hline \multicolumn{3}{|l|}{ Hired services } & 1501.65 & & & 1639.76 \\
\hline Trilla & 1 & 893.74 & 893.74 & 1 & 940.48 & 940.48 \\
\hline Freight & $3.75 \mathrm{t}$ & 162.11 & 607.91 & 4.46 & 156.79 & 699.28 \\
\hline \multicolumn{3}{|l|}{ Direct Costs } & 9069.90 & & & 8205.54 \\
\hline Insurance & 1 & 482.12 & 482.12 & 1 & 419.63 & 419.63 \\
\hline Financing & & & 1968.42 & & & 1968.42 \\
\hline \multicolumn{3}{|l|}{ Indirect Costs } & 2450.54 & & & 2388.05 \\
\hline \multicolumn{3}{|c|}{ Total production cost } & $11,520.44$ & & & $10,593.59$ \\
\hline
\end{tabular}


$13.03 \%$, and indirect costs $21.27 \%$. With this investment, an average yield of $3.75 \mathrm{t} \mathrm{ha}^{-1}$ is obtained. The cost for no-till farming systems was $\$ 10,593.59 \mathrm{ha}^{-1}$, where $53.37 \%$ represent supplies, $15.47 \%$ hired services indirect production costs $22.54 \%$, and land preparation only 8.60\% (Table 3).

For traditional farming systems, benefit-cost ratio was lower than that obtained in no-till farming; in the first one, for every peso invested, the profit was only four mexican peso cents, while in the latter, the profit was 33 cents (Table 4). A similar pattern in B/C indicators was reported with 1.14 for traditional farming and 1.40 for no-till farming, indicating profitability (SAGARPA, 2014). With traditional farming, land preparation has a higher cost.

\section{CONCLUSION}

A lower sorghum yield in 2014-2016 cycles is a proof of the negative effects caused by M. sacchari attack. In addition to a lower yield, the income obtained from grain sales was increasingly smaller due to a downward trend in the purchase price per ton. More frequent insecticide applications were the main control strategy implemented against this pest, which increased production costs. However, the negative effect of $M$. sacchari on the producers' economy was relatively minor since producers have multiple jobs. A medium Management Practices Application Index (IAPM) was obtained for both types of farming types under assessment. However, the higher the IAPM, the higher the yield. Although profits with no-till farming are higher, sorghum cultivation is still considered a profitable activity for the Southwestern region of Puebla state.

\section{ACKNOWLEDGEMENTS}

To the National Council of Science and Technology of Mexico for the grant allowed to the first author.

\section{REFERENCES}

Aguilar, V. (2005). Especies invasoras: Una amenaza para la biodiversidad y el hombre. CONABIO. Biodiversitas: 7-10.

Baca, U.G. (2013). Evaluación de proyectos 7ạ. Edición. Mc Graw-Hill / Interamericana editores S.A. de C.V., México. 371p

Bowling, R.D., Brewer, M.J., Kerns, D.L., Gordy, J., Seiter, N., Elliott N.E., Buntin, G.D., Way, M.O., Royer, T.A., Biles, S. y Maxson. E. (2016). Sugarcane aphid (Hemiptera: Aphididae): a new pest on sorghum in North America. J. Int. Pest Manage. 7(1): 1-13. doi: 10.1093/jipm/pmw011

CESAVEG. (2017). Guía 2017 para el Manejo del Pulgón Amarillo del Sorgo. SAGARPA, SENASICA. 24 p. Obtenido de: http://

\begin{tabular}{|c|c|c|}
\hline & $\begin{array}{l}\text { Traditional } \\
\text { Farming }\end{array}$ & $\begin{array}{l}\text { No-Till Farming } \\
\text { (Zero) }\end{array}$ \\
\hline Yield (t ha ${ }^{-1}$ ) & 3.75 & 4.46 \\
\hline Cost $\left(\$ h a^{-1}\right)$ & $11,520.44$ & $10,593.59$ \\
\hline Sale price $\left(\$ t^{-1}\right)$ & 3202.63 & $3,179.76$ \\
\hline Sales Revenue $\left(\$ \mathrm{ha}^{-1}\right.$ ) & $12,009.86$ & $14,181.72$ \\
\hline Net income per ha $\left(\$ \mathrm{ha}^{-1}\right)$ & 489.42 & 3588.13 \\
\hline Net income per $t\left(\$ t^{-1}\right)$ & 130.51 & 804.51 \\
\hline Cost-Benefit Ratio & 1.04 & 1.33 \\
\hline
\end{tabular}

Developed by author.

www.pulgonamarillogto.com/exteduc/publicaciones/guia_ MIPulgonamarillo_2017.pdf. ISBN: 978-607-96123-4-4

Damián-Huato, M.A., Ramírez-Valverde, B., Aragón-García, A., LópezOlguín, J.F. (2011). Diversificación económica, siembra de maíz y rendimientos de los productores del estado de Tlaxcala, México. Econ. Soc. Territ. 11 (36): 513-537. ISSN 2448-6183

Damián-Huato, M.A.D., Cruz, A., Sangerman-Jarquín, M, López, L., Carcaño, M., Romero, O. (2019). Modelo productor-innovador y autosuficiencia alimentaria para milperos de secano: Propuesta de política pública sostenible. Scripta Nova. 19 p. DOI: https://doi.org/10.1344/sn2019.23.21902

FAO. (2001). El Estado Mundial de la Agricultura y la Alimentación. No. 33. $314 \mathrm{p}$.

FAO. (2012). Marco estratégico de mediano plazo de cooperación de la FAO en agricultura familiar en América Latina y el Caribe. $45 \mathrm{p}$.

Haar P. J Buntin G. D., Jacobson A., Pekarcik A., Way M. O., and Zarrabi A. 2019. Evaluation of Tactics for Management of Sugarcane Aphid (Hemiptera: Aphididae) in Grain Sorghum. Journal of Economic Entomology, 112(6), 2719-2730; doi: 10.1093/jee/ toz215

INIFAP-CIRNE, (2015). El pulgón amarillo, una nueva plaga del sorgo en México. Boletín Electrónico 1(16): 1-3.

Oliveira, C.M., Auad, A.M., Mendes, S.M., Frizzas, M.R. (2013). Crop losses and the economic impacto of insect pest on Brazilian agriculture. Crop Prot. 56: 50-54. https://doi.org/10.1016/j. cropro.2013.10.022

Rivas, A.W., Sermeño, J.M. (2004). Manual técnico: Socioeconomía del Manejo Integrado de Plagas. Universidad de El Salvador, Fac. Ciencias Agronómicas. 97 p

SAGARPA. (2012). Plan rector del sistema producto sorgo. Estado de Puebla. 49 p.

SAGARPA. (2014). Estudio estratégico "Evaluación y determinación de la escala mínima rentable, de unidades productivas para emprendedores en el campo poblano".

SAGARPA-INIFAP. (2017). Guía para el manejo del pulgón amarillo del sorgo. 36 p. ISBN: 978-607-96123-4-4

Savary, S., Mille, B., Rolland, B., Lucas, P. (2006a). Patterns and management of crop multiple pathosystems. Eur. J. Plant Pathol. 115(1): 123-138. https://doi.org/10.1007/s10658-005-0651-z

Savary, S., Teng, P., Willocquet, L., Nutter, F.J. (2006b). Quantification and modeling of crop losses: a review of purposes. Ann. 
Rev. Phytopathol. 44: 89-112. DOI: 10.1146/annurev. phyto.44.070505.143342

SIAP. (2017). Anuario estadístico de la producción agrícola. Obtenido de http://nube.siap.gob.mx/cierre_agricola/

SIAP. (2019). Anuario estadístico de la producción agrícola. Obtenido de http://nube.siap.gob.mx/cierre_agricola/

Singh, B. U., Padmaja, P.G., Seetharama, N. (2004). Biology and management of the sugarcane aphid, Melanaphis sacchar (Zehntner) (Homoptera:Aphididae), in sorghum: a review. Crop Prot. 23: 739-755. DOI: 10.1016/j.cropro.2004.01.004

Sobrado. (2005) Cited in: SAGARPA.2012. Plan rector del sistema producto sorgo. Estado de Puebla. $49 \mathrm{p}$

Vargas, G. (2009). Producción y comercialización de sorgo grano en México y en el estado de Puebla: Caso DDR Izúcar de Matamoros. Tesis. Universidad Autónoma Agraria Antonio Narro. Saltillo, México. 58 p

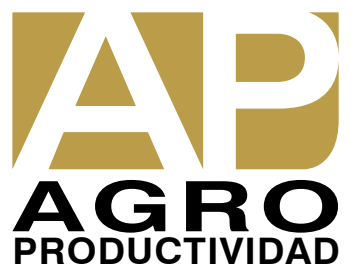

